\title{
DIVERSITY OF LEAF ENDOPHYTIC FUNGI IN MANGROVE PLANTS OF NORTHEAST BRAZIL
}

\author{
Isabella P. M. Wanderley Costa; Leonor Costa Maia; Maria Auxiliadora Cavalcanti*
}

Departamento de Micologia, Universidade Federal de Pernambuco, Cidade Universitária, Recife, PE, Brasil.

\begin{abstract}
With the aim of increasing the knowledge about endophytic fungi, a group of microorganisms with high biotechnological potential and a valuable source of useful metabolites, a survey in leaves of mangrove plants (Avicennia schaueriana, Laguncularia racemosa, and Rhizophora mangle) was performed at the Itamaracá Island, PE, Brazil. Leaves were collected, during two seasons, dry and rainy, superficially sterilized and fragments maintained in Petri dishes with Potato dextrose agar (PDA) at $28^{\circ} \pm 2^{\circ} \mathrm{C}$ until isolation of the fungi. Fourty taxa were isolated: 25 species representing 19 genera and 15 morphotypes determined as Mycelia sterilia. Leaves of L. racemosa hosted the highest number of colony forming units (CFU) and taxa. Guignardia sp. and Colletotrichum gloeosporioides were the most frequently isolated, while Glomerella cingulata was the only species found in association with the three host plants. The proportional importance of each fungus differed among hosts. The similarity of fungi species between the two seasons reached only $4.2 \%$, and that between the hosts was also low, with the maximum ( $A$. schaueriana x L. racemosa) reaching 24.2\%. Sphaerosporium, as well as Chloridium virescens var. virescens, Microsphaeropsis arundinis, Penicillium pinophilum, Periconia cambrensis, Phoma herbarum, P. diachenii, P. obscurans, Sordaria prolifica and Torula elisii are reported for the first time as endophytic in tropical regions.
\end{abstract}

Key words: Aviccenia, conidial fungi, Laguncularia, Rhizophora.

\section{INTRODUCTION}

The endophytic fungi are microorganisms that invade the tissues of plants during their life cycle without causing disease symptoms, and many are important in biotechnological processes (2), producing a high diversity of substances with potential medical, agricultural, and industrial application (24, $29,36,51,53)$. The isolation, culture, and characterization of some endophytes have provided opportunity for discovery of novel antibiotics, antimycotics, immunosuppressants, and anticancer compounds, among other products (54). Colutellin A, for example, is a novel antimycotic peptide, produced by a species of Colletotrichum ( $C$. dematium) recovered as endophytic from a Pteromischum species growing in a tropical forest in Costa Rica (44); from C. gloeosporioides, endophytic of Viguiera robusta Gardn. (Asteraceae), eight biologically active substances were isolated (7), showing the potential of the endophytic fungi. Possibly present in all terrestrial plant

*Corresponding Author. Mailing address: Departamento de Micologia, Universidade Federal de Pernambuco 50670-420 Recife - PE - Brasil.; Tel.: 55-8121268478.; E-mail: xilimac@terra.com.br 
species, the fungal endophytes are distributed in temperate $(6$, $12,16,17,18,19,39)$ and tropical $(9,21,28,47,55,56)$ regions, in different biomes and ecosystems, including mangroves $(20,26,27,28,32,55)$. Plants from this particular ecosystem present a consortium of soil, marine, and freshwater fungi (1). However, not much is known about endophytic fungi in mangroves, which is a peculiar habitat, in many cases exposed to hard man pressure.

Considering the absence of records regarding endophytic fungi in Brazilian mangroves a survey in leaves of Avicennia schaueriana Stapf. \& Leechman (black mangrove), Laguncularia racemosa (L.) Gaertn. F. (white mangrove), and Rhizophora mangle L. (red mangrove) was performed at the Northeast coast of the country. Studies to investigate the relations between occurrence of these organisms, hosts, and season were also performed.

\section{MATERIALS AND METHODS}

Leaves were collected from a mangrove area at the Itamaracá Island, north coast of the State of Pernambuco $\left(7^{\circ} 34^{\prime} 00^{\prime \prime}-7^{\circ} 55^{\prime} 16^{\prime \prime} \mathrm{S}, 34^{\circ} 48^{\prime} 48^{\prime \prime}-34^{\circ} 52^{\prime} 24^{\prime \prime} \mathrm{W}\right)$, Northeast Brazil. This estuarine system covers an area of $82 \mathrm{Km}^{2}$. The weather is tropical rainy with dry summer (September to February) and a rainy season (March to August), average temperature $28^{\circ} \mathrm{C},>80 \%$ humidity, and precipitation $1.870 \mathrm{~mm} /$ year.

Two collections were undertaken during the dry season (November and February) and two during the rainy season (June and July). Samples of healthy mature living symptomless leaves from two mature trees of three common mangrove species of different families (Avicennia schaueriana Avicenniaceae, Laguncularia racemosa - Combretaceae, and Rhizophora mangle- Rhizophoraceae) were chosen at random, collected, stored in a cool box above ice, taken to the laboratory and processed. The leaves, in a total of 18/collection, were washed thoroughly in running water, surface sterilized in $70 \%$ ethanol (5 s), immersed in $4 \% \mathrm{NaOCl}(90 \mathrm{~s})$, rinsed in sterile distilled water for $10 \mathrm{~s})$ (12) and from each leaf lamina, six pieces approx $0.5 \mathrm{~mm}^{2}$ were excised from the tip, middle and base; each set of subsamples was placed onto a half-strength Potato dextrose agar (PDA) (plus chloranphenicol) Petri plate. All plates were maintained at room temperature $\left(28^{\circ} \pm 1\right)$ and daily examined during four weeks for fungal colonies growing from the leaf fragments. For each collection 108 segments were examined and the endophytic fungi that grew from each leaf segment transferred to glass tubes with PDA for identification.

To induce sporulation some fungi were transferred to other growth medium such as Malt agar, Oatmeal agar, Czapek and Sabouraud, and some exposed to UV-light for $30 \mathrm{~s}$.

The frequency of occurrence of each fungus was determined and the Qui Square test used to evaluate significant differences in number of colonies in each plant species and season. The $\mathrm{Z}$ test $(P<0.5)$ was applied to detect differences in the total number of colonies in the dry and rainy seasons and in number of colonies obtained from leaves of Laguncularia racemosa between the seasons. The similarity of fungi between the plant species was estimated by the Sorensen index. Diversity and equitability were determined by the Shannon index and species dominance obtained by the Berger-Parker index. The EPI-INFO program (13) was used for the statistical analysis.

\section{RESULTS}

From the three plant species (432 leaf fragments), 246 fungal colony forming units (CFU) were obtained and 24 species of endophytic fungi belonging to 19 genera were identified, most in the anamorphic (Hyphomycetes) group. Despite many attempts using different culture media, 15 isolates did not sporulate being classified as Mycelia sterilia and distinguished based on color (dark or light mycelium) and morphological aspect of the colonies. From those, two were from leaves of $A$. schaueriana and seven and eight from $L$. 
racemosa and $R$. mangle, respectively.

The highest numbers of CFU were from Guignardia sp. and Colletotrichum gloeosporioides, with 55 and 40 colonies, respectively. Fifty colonies of Guignardia were isolated from leaves of L. racemosa and only five from R. mangle. Most of the 37 colonies of C. gloeosporioides were originated from leaves of A. schaueriana, mainly in the dry season, and only three were isolated from L. racemosa, in the rainy season. Phomopsis diachenii, Phyllosticta sp. and Nodulisporium gregarium, Glomerella cingulata and Phomopsis archeri were the other most representative species recorded in the study (Table 1).

Leaves of L. racemosa hosted the highest number of CFU and taxa (108 and 20, respectively), in both seasons, followed by A. shaueriana, from which 13 taxa (2 Mycelia sterilia) and 93 CFU were isolated. From leaves of $R$. mangle only six species (plus 8 Mycelia sterilia) were identified from 45 CFU (Table 1).

Table 1. Colony forming units (CFU) of endophytic fungi isolated from leaves of Avicennia schaueriana (A), Laguncularia racemosa (L) and Rhizophora mangle (R) during the dry (D) and rainy (R) seasons of 2001 and 2002, at the Paripe River mangrove, Itamaracá Island, PE, Brazil

\begin{tabular}{|c|c|c|c|c|c|c|c|}
\hline \multirow[t]{2}{*}{ Genus/Species } & \multicolumn{3}{|c|}{ Dry } & \multicolumn{3}{|c|}{ Raining } & \multirow[b]{2}{*}{ Total CFU } \\
\hline & $\mathbf{A}$ & $\mathbf{L}$ & $\mathbf{R}$ & $\mathbf{A}$ & $\mathbf{L}$ & $\mathbf{R}$ & \\
\hline Chloridium virescens var. virescens (Pers.) W. Gams \& Hol. - Jech. & - & - & - & 1 & - & - & 1 \\
\hline Colletotrichum gloeosporioides (Penz.) Penz. \& Sacc. & 26 & - & - & 11 & 3 & - & 40 \\
\hline Fusarium lateritium Nees & - & 1 & - & - & - & - & 1 \\
\hline Glomerella cingulata (Stoneman) Spauld. \& H. Schrenk & 1 & 1 & - & 11 & 2 & 2 & 17 \\
\hline Guignardia sp. & - & 31 & - & - & 19 & 5 & 55 \\
\hline Hormonema anamorph Dothiora europaea Froid. & - & 4 & - & - & - & - & 4 \\
\hline Microsphaeropsis arundinis (S. Ahmad) B. Sutton & - & 4 & - & - & - & - & 4 \\
\hline Nodulisporium anamorph Hypoxylon fragiforme Pers. ex Fr. & - & - & - & - & 1 & - & 1 \\
\hline Nodulisporium gregarium (Berk.\&M. A.Curtis) J. A. Mey. & - & - & 1 & 15 & - & 3 & 19 \\
\hline Penicillium pinophilum Hedgcock & - & - & - & - & 5 & - & 5 \\
\hline Periconia cambrensis E. W. Mason \& M. B. Ellis & - & - & 2 & - & - & - & 2 \\
\hline Periconia anamorph Didymosphaeria igniaria C. Booth & - & - & - & 2 & - & - & 2 \\
\hline Phoma eupyrena Sacc. & - & 1 & - & - & - & - & 1 \\
\hline P. herbarum Westend. & - & - & - & - & 1 & - & 1 \\
\hline Phomopsis archeri $\mathrm{B}$. Sutton & 8 & 4 & - & 1 & 2 & - & 15 \\
\hline P. diachenii Sacc. & 5 & 19 & - & - & - & - & 24 \\
\hline P. obscurans (Ellis \& Everh.) B. Sutton & - & 2 & - & - & - & - & 2 \\
\hline Phyllosticta sp. & - & - & 17 & - & - & 2 & 19 \\
\hline Preussia minima (Auersw.) Arx & - & - & - & 1 & - & - & 1 \\
\hline Scopulariopsis sphaerospora Zach & 1 & - & - & - & - & - & 1 \\
\hline Sordaria prolifica Cailleux & 6 & - & - & - & - & - & 6 \\
\hline Sphaerosporium equinum (Desm.) J. L. Crane \& Schokn. & - & - & 5 & - & - & - & 5 \\
\hline Torula ellisii Yadav \& Lal & - & - & - & 2 & - & - & 2 \\
\hline Trichoderma pseudokoningii Rifai & - & - & - & - & 1 & - & 1 \\
\hline Mycelia sterilia white I & - & - & 1 & - & - & - & 1 \\
\hline Mycelia sterilia white II & - & - & 1 & - & - & - & 1 \\
\hline Mycelia sterilia white III & - & 1 & - & - & - & - & 1 \\
\hline Mycelia sterilia white IV & - & 1 & - & - & - & - & 1 \\
\hline Mycelia sterilia white V & - & - & - & - & 2 & - & 2 \\
\hline Mycelia sterilia white VI & - & - & - & - & - & 1 & 1 \\
\hline Mycelia sterilia white VII & - & - & - & - & 1 & - & 1 \\
\hline Mycelia sterilia white VIII & - & - & - & - & - & 1 & 1 \\
\hline Mycelia sterilia white IX & - & - & - & - & - & 1 & 1 \\
\hline Mycelia sterilia white $\mathrm{X}$ & - & - & - & 1 & - & 1 & 2 \\
\hline Mycelia sterilia dark I & - & - & 1 & - & - & - & 1 \\
\hline Mycelia sterilia dark II & 1 & - & - & - & - & - & 1 \\
\hline Mycelia sterilia dark III & - & 1 & - & - & - & - & 1 \\
\hline Mycelia sterilia dark IV & - & - & - & - & - & 1 & 1 \\
\hline Mycelia sterilia dark V & - & - & - & - & 1 & - & 1 \\
\hline TOTAL & 48 & 70 & 28 & 45 & 38 & 17 & 246 \\
\hline
\end{tabular}


Glomerella cingulata was the only species isolated from the three plant hosts. Guignardia sp. was mostly isolated from $L$. racemosa (50 CFU), C. gloeosporioides (37 CFU) from $A$. schaueriana and Phyllosticta sp. (19 CFU) from R. mangle, the only host from which it was isolated.

During the dry season C. gloeosporioides, from leaves of $A$. schaueriana (54.2\%), Guignardia sp. from L. racemosa (44.3\%) and Phyllostica, from R. mangle, were the most frequently isolated species, while in the rainy season this occurred with $N$. gregarium (33.3\%) and Guignardia (50\% and 29.4\%), isolated respectively from leaves of A. schaueriana, L. racemosa, and R. mangle. The proportional importance of the species was confirmed by the Berger-Parker dominance index. In leaves of $A$. schaueriana, $C$. gloeosporioides $(\mathrm{pi}=0.54), P$. archerii $(\mathrm{pi}=0.16)$, . prolific $(\mathrm{pi}$ $=0.12)$ and $P$. diachenii $(\mathrm{pi}=0.104)$ were the most dominant in the dry season, while G. cingulata $(\mathrm{pi}=0.44), N$. gregarium $(\mathrm{pi}=$ 0.33 ), and C. gloeosporioides dominated the population in the rainy season. In leaves of L. racemosa, the dominants in the dry and rainy season were respectively: Guignardia $\mathrm{sp} .(\mathrm{pi}=0.44)$ and $P$. diachenii $(\mathrm{pi}=0.27)$ and Guignardia sp. and $P$. pinophilum. Regarding leaves of R. mangle, Phyllosticta sp. $(\mathrm{pi}=0.60)$ and $S$. equinum $(\mathrm{pi}=0.17)$ in the dry season and Guignardia $\mathrm{sp}$. (pi =
0.29), N. gregarium (pi =0.17), and both Phyllosticta sp. and $G$. cinculata ( $\mathrm{pi}=0.11$ ) in the rainy season were the dominant species. The other species presented a low $(<0.1)$ dominance index or were not proportionally important.

The Shannon Diversity Index in the dry season was $\mathrm{H}^{\prime}=$ 1.035 , and a little lower in the rainy season $\left(H^{\prime}=1.026\right)$. In relation to species equitability, the highest index (Shannon) was registered during the rainy season, in Rhizophora $(\mathrm{J}=0.91)$. For this host, in the dry season the value was much lower $(\mathrm{J}=0.65)$. For Avicennia the index of equitability of fungi varied from 0.70 to 0.76 and in Laguncularia from 0.67 to 0.73 , respectively in the dry and rainy season.

The number of CFU (Fig. 1) did not differ between the dry and the rainy seasons in leaves of $A$. schaueriana and $R$. mangle $\left(\mathrm{X}^{2}=3.8\right)$ but significant difference occurred in leaves of $L$. racemosa $(\mathrm{p}=0.025 ; \mathrm{Z}=2.235 . \mathrm{p}=0.05)$. When the two periods were compared, considering the three hosts, a significant difference on CFU was registered $(p=0.008 ; Z=2.645$. $p=1.0)$.

The similarity of fungal species between the two seasons reached only $4.2 \%$, and that between the hosts was also low, as follows: $L$. racemosa and $R$. mangle $=11.7 \%$; A. schaueriana and R. mangle $=12.2 \%$; A. schaueriana and L. racemosa $=24.2 \%$.

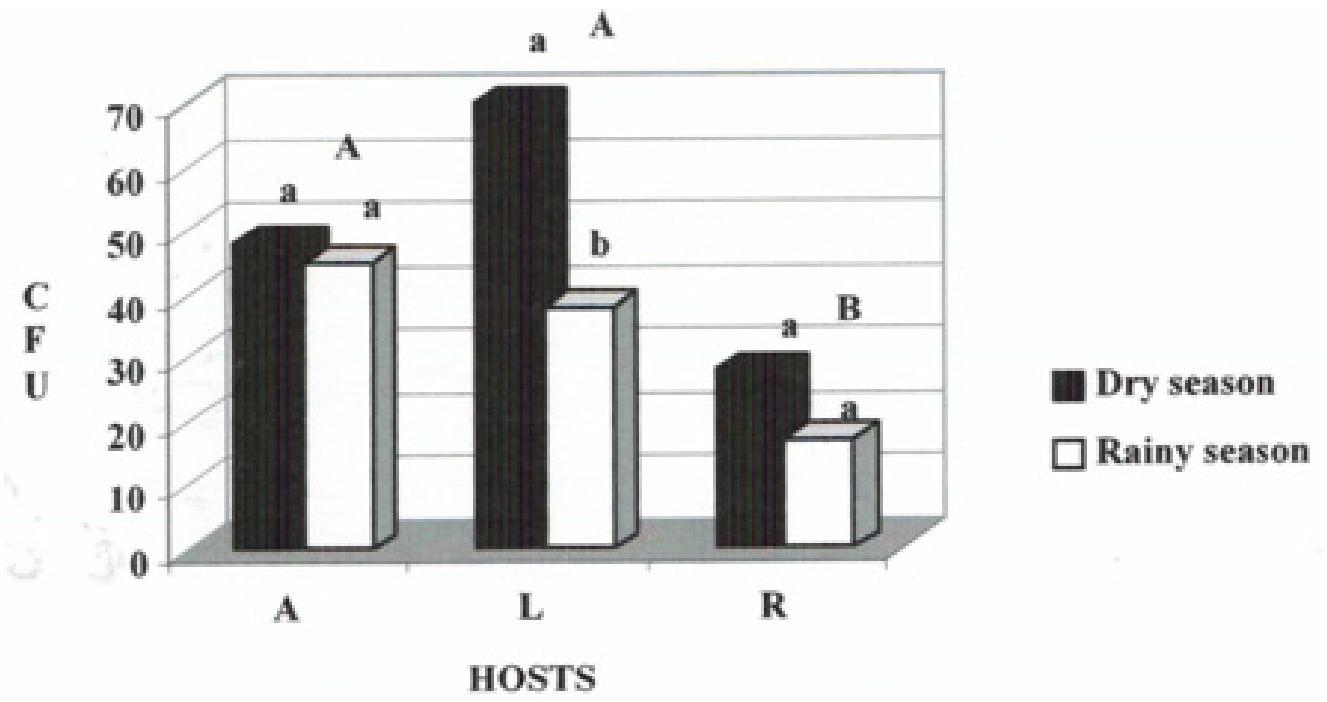

Figure 1. Fungal colony forming units (CFU) of endophytic fungi in Avicennia schaueriana (A), Laguncularia racemosa (L) and Rhizophora mangle (R) isolated during dry and rain seasons. Small letters compare the seasons with CFU of each host. Capital letters compare the CFU among the hosts independently of the seasons. 


\section{DISCUSSION}

The most common isolation of anamorphic and sterile fungi (Mycelia sterilia) in relation to Ascomycota or Basidiomycota teleomorphs agree with data obtained in other studies $(41,43)$ including some in mangrove communities with Rhizophora apiculata and R. mucronata (55), and Aegiceras corniculatum, Avicennia marina, A. officinalis, Bruguiera cylindrical, Ceriops decandra, Excoecaria agallocha and Lumnitzera racemosa (26). The number of species identified as endophyte varies among the studies and in some cases high number of samples does not imply in high species richness. Rodrigues and Samuels (49) recovered only 13 species from 1512 samples of Spondias mombin, while 22 species were indentified in 630 samples of Manikara bidentata (28). In our study, 24 species were identified from 432 leaf fragments what indicates that the data fits the expected results. Many factors are associated with differences on number of recovered endophytic species, among which the size of the fragment, the part of the plant, difficulties for identification, etc.

A high number of cultures did not sporulate as also reported in other studies with endophytes $(41,43,56)$. The artificial culture media do not offer the same set of conditions to which the fungi are adapted in the special microhabitat found in their host plants.

Some studies have suggested that geographical rather than plant-linked factors may be more important in determining species composition (9). However, certainly the host species contributes for establishment of the fungi, considering that its community differs among plants growing in the same area, as found in the studied mangrove, where the similarity index of fungi between the plant species was relatively low.

A host preference pattern was not identified, as observed also in other studies with tropical endophytic fungi (9) and some of the species reported in only one host were in fact rarely found. But it is worth mention that two of the hosts $(A$. schaueriana $93 \mathrm{CFU}$ and L. racemosa $108 \mathrm{CFU}$ ) presented a number of colonies distinctly higher than the other (R. mangle $45 \mathrm{CFU})$, indicating that some factors, not identified, make $A$. schaueriana and L. racemosa more suitable for the establishment of fungal endophytes than $R$. mangle. On the other hand, this was not confirmed by the species richness, similar between $A$. schaueriana and $R$. mangle and substantially higher in L. racemosa.

Colletotrichum gloeosporioides was isolated only from two hosts although its teleomorph ( $G$. cingulata) had been isolated from the three hosts. Similar results were obtained with Phyllosticta sp., found only in one of the hosts $(R$. mangle) while its teleomorph (Guignardia sp.) was isolated from $R$. mangle and L. racemosa, where it dominated the population of fungi. Usually the anamorphic phase is more common than the teleomorphic, but the results show that the environmental/cultural conditions were suitable for expression of the complete (sexual) life cycle of these fungi.

Glomerella cingulata, Guignardia sp. and their anamorphs are among the most common endophytic fungi in many subtropical and tropical hosts $(26,27,28,37,38,41,43$, 55, 49), as also occurs with Fusarium (9, 18, 19, 30). Fusarium lateritium, however, was found only in Compositae (41), and this study confirms its endophytic status. Colletotrichum sp., Acremonium sp. and Penicillium sp. dominated as endophytes in two halophyte plants in a West Coast mangrove of India (5), and an endophytic isolate of $C$. gloeosporioides has been shown to produce antifungal metabolites (23).

Species of Microsphaeropsis were isolated from Compositae (20) and Palmae (21), but the genus is typically found as saprobe and parasite of terrestrial plants and rarely found as endophytic in the tropics; $M$. arundinis, isolated in this study, was never cited as such. Reports also show $M$. arundinis as the causal agent of infections in human (40) and animals (25).

Although many species of Aspergillus and Penicillium are endophytic (30) in this study no species of Aspergillus were 
isolated and only one species of Penicillium ( $P$. pinophilum) was identified. $P$. pinophilum is an important producer of enzymes and secondary metabolites, some of which are promising to include in strategies for treatment of cancer $(3,8)$. Interestingly, $P$. pinophilum was recently found forming arbuscular mycorrhiza with strawberry 'Zoji' (Fragaria $\times$ ananassa Duch. CV.), and this seems to be the first report of a fungus that do not belong to the Glomeromycota forming arbuscular mycorrhiza (14).

Periconia anamorph of Didymosphaeria igniaria was previously recognized as endophyte in Compositae and Leguminosae $(5,41,43,45)$. Recently D. igniaria was indicated as a promising biocatalyst, useful for the reduction of aryl-aliphatic ketones (57).

Other common endophytes are Trichoderma (9, 20, 21, 28, 48, 49), Phoma, Phomopsis (59, 19, 21, 27, 30, 36, 41, 42, $45,46,49,52,55)$ and many xylariaceous fungi such as Nodulisporium anamorph Hypoxylon fragiforme (4, 19, 41, 46). However, this is the first report of $T$. pseudokoningii, Phoma eupyrena, Phomopsis diachenii and P. obscurans, which are well known parasites $(30,31,35,36)$, as endophytic in tropical hosts. The same occurs with Chloridium virescens var. virescens, Scopulariopsis sphaerospora, Sphaerosporium equinum, Sordaria prolifica, and Torula ellisii. Chloridium virescens var. virescens, a typical saprophyte, was reported in leaf litter in Brazil $(11,22)$.

Some genera of endophytic fungi isolated in this study are known as pathogenic in several plants, including mangrove species: Phyllosticta, Colletotrichum, Glomerella and $P$. eupyrena were reported as causing necrosis or leaf spots in Avicennia germinan, L. racemosa, and $R$. mangle, respectively. Fusarium, Penicillium, Trichoderma, Scopulariopsis, Phoma and Phomopsis were also found as pathogens on such plant hosts $(15,34)$. In spite of being pathogens, several fungi are primarily endophytic, behaving as latent pathogens and later turning epiphytic and expressing pathogenicity, with the endophytism representing a phase in their life cycle (41). For some, "the endophytes, in contrast to known pathogens, generally have far greater phenotypic plasticity and thus more options than pathogens: infection, local but also extensive colonization, latency, virulence, pathogenicity and (or) saprophytism" (50). Coprophylous fungi can also be found as endophyte and, among them Sporormiella minina=Preussia minina, found only once in this study, is the most recorded (20, $26,41,55)$.

Usually one to a few taxa of endophytic fungi predominate in a single host $(26,55)$, what can be the result of specificity for tissues $(43,46)$ and hosts $(26,55)$. Other factors such as competition for space and antagonism should also be considered. The results showed that a few species dominated the population in the three host plants and from these $G$. cingulata and its anamorph (C. gloeosporioides), P. diachenii, Guignardia sp. Phyllosticta sp., and N. gregarium were more common.

Differences in number of CFU and richness of fungi, higher in L. racemosa in comparison with the other hosts may express host characteristics. Species of Rhizophoraceae have high concentration of tannin, a phenolic substance that can inhibit fungal growth and members of Avicennia present high concentration of salt on their leaves (58), what probably select the endophytic mycota.

Our data showing higher number of CFU during the dry season differ from that of other authors $(47,55)$, who isolated more endophytic fungi during the rainy season. However, the year of our collection was atypical, with high rates of precipitation during the usually "dry season". In other study (21) populations of endophytic fungi were not affected by the seasons of the year. Maria and Sridhar (33) found significant differences in the species diversity and expected number of species between the seasons in studies of wood litter at a mangrove stand of Southwest coast of India. Probably the community of fungi in the litter reflects also that found as endophytic which can live as saprophyte when parts of the plant fall down. 
Some records of endophytic fungi producers of important compounds have no identification (10), others that deal with diversity present the endophytic fungi at genus and sometimes family levels what makes it difficult to compare the studies, but it is evident the high diversity of fungi living into plant tissues. The problems for sporulation of many taxa and the decreasing number of taxonomists contribute for incomplete identifications but should not impair the investigations about this interesting group of fungi, known for its high biotechnological potential, as source of bioactive and chemically novel compounds which can be employed in agricultural, industrial and medical areas. Further investigations will be performed in order to better characterize the biotechnological potential of the endophytes isolated in this study.

\section{ACKNOWLEDGEMENTS}

The authors are in debt with Dr. José Luis Bezerra and Dr. Tatiana Gibertoni for suggestions, Ma. José Fernandes and Débora Maria M. Lima for confirming the identification of some species, Monica Barradas, for helping with the statistical analysis, Dr. Bruno T.Goto and Dr. José Z. Passavante for helping with the collections. The Coordenação de Aperfeiçoamento de Pessoal de Nível Superior (CAPES) and Conselho Nacional de Desenvolvimento Científico e Tecnológico $(\mathrm{CNPq})$ are also acknowledged for providing, respectively, a Master's scholarship to the first author and grant support to M.A. Cavalcanti and L.C. Maia.

\section{REFERENCES}

1. Ananda, K.; Sridhar, K.R. (2002). Diversity of endophytic fungi in the roots of mangrove species on the west coast of India. Can. J. Microbiol. 48, 871-878.

2. Azevedo, J.L.; Júnior, W.M.; Pereira, J.O.; Araújo, W.L. (2000). Endophytic microorganisms: a review on insect control and recent advances on tropical plants. Eletron. J. Biotech. 3, 40-65.

3. Baroni, A.; De Luca, A.; De Filippis, A.; Petrazzuolo, M.; Manente,
L.; Nicoletti, R.; Tufano, M. A.; Buommino, E. (2009). 3-Omethylfunicone, a metabolite of Penicillium pinophilum, inhibits proliferation of human melanoma cells by causing $\mathrm{G}_{2}+\mathrm{M}$ arrest and inducing apoptosis. Cell Proliferation 42, 541-553.

4. Bayman, P.; Angulo-Sandoval, P.; Báez-Ortiz, Z.; Lodge, D.J. (1998). Distribution and dispersal of Xylaria endophytes in two tree species in Puerto Rico. Mycol. Res. 102, 944-948.

5. Beena, K.R.; Ananda, K.; Sridhar, K.R. (2000). Fungal endophytes of three sand dune plant species of west coast of India. Sydowia 52, 1-9.

6. Bills, G.F.; Polishook, J.D. (1992). Recovery of endophytic fungi from Chamaecyparis thyoides. Sydowia 44, 1-12.

7. Borges, W.S. (2008). Estudo de fungos endofiticos associados a plantas da família Asteraceae como fonte de metabólitos secundários e em processos de biotransformações. São Paulo, Brasil, (M.Sc. Thesis, USP, Ribeirão Preto).

8. Buommino, E.; Paoletti, I.; De Filippis, A.; Nicoletti, R.; Ciavatta, M. L.; Menegozzo, S.; Menegozzo, M.; Tufano, M. A. (2010). 3-OMethylfunicone, a metabolite produced by Penicillium pinophilum, modulates ERK1/2 activity, affecting cell motility of human mesothelioma cells. Cell Proliferation 43, 114-123.

9. Cannon, P.F.; Simmons, C.M. (2002). Diversity and host preference of leaf endophytic fungi in the Iwokrama Forest Reserve, Guyana. Mycologia 94, 210-220.

10. Chen, G.; Lin, Y.; Wen, L.; Vrijmoed, L.L.P.; Gareth-Jones, E.B. (2003). Two new metabolites of a marine endophytic fungus (No. 1893) from an estuarine mangrove on the South China Sea coast. Tetrahedron 59, 49074909.

11. Cruz, A.C.R.; Marques, M.F.O.; Gusmão, L.F.P. (2007). Fungos anamórficos (Hyphomycetes) da Chapada Diamantina: novos registros para o Estado da Bahia e Brasil. Acta Bot. Bras. 21, 847-855.

12. Dobranic, J.K.; Johnson, J.A.; Alikhan, Q.R. (1995). Isolation of endophytic fungi from eastern larch (Larix laricina) leaves from New Brunswick, Canada. Can. J. Microbiol. 41, 194-198.

13. EPI-INFO. (2001). Versão 6.04d.

14. Fan, Y.; Luan, Y.; An, L.; Yu, K. (2008). Arbuscular mycorrhizae formed by Penicillium pinophilum improve the growth, nutrient uptake and photosynthesis of strawberry with two inoculum-types. Biotech. Letters 30, 1489-1494

15. Farr, D.F.; Bills, G.F.; Chamuris, G.P.; Rossman, A.V. (1989). Fungi on plants and plant products in the United States. APS Press, Minnesota.

16. Fisher, P.J.; Anson, A.E.; Petrini, O. (1986). Fungal endophytes in Ulex europaeus and Ulex gallii. Trans. Br. Mycol. Soc. 86, 153-193.

17. Fisher, P.J.; Petrini, O. (1987). Location of fungal endophytes in tissues of Suaeda fruticosa: A preliminary study. Trans. Br. Mycol. Soc. 89, 246-249.

18. Fisher, P.J.; Petrini, O.; Petrini, L.E.; Sutton, B.C. (1994a). Fungal endophytes from the leaves and twigs of Quercus ilex L. from England, 
Majorca and Switzerland. New Phytol. 127, 133-137.

19. Fisher, P.J.; Sutton, B.C.; Petrini, L.E.; Petrini, O. (1994b). Fungal endophytes from Opuntia stricta: a first report. Nova Hedwigia 59, 195200.

20. Fisher, P.J.; Petrini, L.E.; Sutton, B.C.; Petrini, O. (1995). A study of fungal endophytes in leaves, stems and roots of Gynoxis oleifolia Muchler (Compositae) from Ecuador. Nova Hedwigia 60, 589-594.

21. Fröhlich, J.; Hyde, K.D.; Petrini, O. (2000). Endophytic fungi associated with palms. Mycol. Res. 104, 1202-1212.

22. Grandi, R.A.P.; Attili, D.S. (1996). Hyphomycetes on Alchornea triplinervia (Spreng.) Müell. Arg. leaf litter from the Ecological Reserve Juréia-Itatins, State of São Paulo, Brazil. Mycotaxon 60, 373-386.

23. Inácio, M.L.; Silva, G.H.; Teles, H.L.; Trevisan, H.C.; Cavalheiro, A.J.; Bolzani, V.S.; Young, M.C.M.; Pfenning, L.H.; Araújo, A.R. (2006). Antifungal metabolites from Colletotrichum gleosporioides, an endophytic fungus in Cryptocarya mandioccana Nees (Lauraceae). Biochem. Syst. Ecol. 34, 822-824.

24. Kharwar, R.N.; Verma, V.C.; Kumar, A.; Gond, S.K.; Harper, J.K.; Hess, W.M.; Lobkowosky, E.; Ma, C.; Ren, Y.; Strobel, C.A. (2009). Javanicin, an antibacterial Naphtaquinone from an endophytic fungus of Neem, Chloridium sp. Curr. Microbiol. 58, 233-238.

25. Krockenberger M.B.; Martin, P.; Halliday, C.; Rothwell, T.L.; Clarke, K.; Malik R. (2010). Localised microsphaeropsis arundinis infection of the subcutis of a cat. J. Feline Med. Surg. 12, 231-6.

26. Kumaresan, V.; Suryanarayanan, T.S. (2001). Occurrence and distribution of endophytic fungi in a mangrove community. Mycol. Res. 105, 1388-1391.

27. Kumaresan, V.; Suryanarayanan, T.S. (2002). Endophyte assemblages in young, mature and senescent leaves of Rhizophora apiculata: evidence for the role of endophytes in mangrove litter degradation. Fungal Divers. 9, 81-91.

28. Lodge, D.J.; Fisher, P.J.; Sutton, B.C. (1996). Endophytic fungi of Manilkara bidentata leaves in Puerto Rico. Mycologia 88, 733-738.

29. Maciá-Vicente, J.G.; Jansson, H-B.; Mendgen, K.; Lopez-Llorca, L.V. (2008). Colonization of barley roots by endophytic fungi and their reduction of take-all caused by Gaeumannomyces graminis var. tritici Can. J. Microbiol. 54, 600-609.

30. Magalhães, W.C.S.; Missagia, R.V.; Costa, F.A.F.; Costa, M.C.M. (2008). Diversidade de fungos endofíticos em candeia Eremanthus erythropappus (DC.) MacLeish. Cerne 14, 267-273.

31. Machowicz-Stefaniak, Z. 2009. The occurrence and biotic activity of Phomopsis diachenii Sacc. Acta Agrobotanica 62, 125-135.

32. Maria, G.L.; Sridhar, K.R. (2003a). Endophytic fungal assemblage of two halophytes from west coast mangrove habitats, India. Czech Mycol. 55, 241-251.

33. Maria, G.L.; Sridhar, K.R. (2003b). Diversity of filamentous fungi on woody litter of five mangrove plant species from the southwest coast of
India. Fungal Divers. 14, 109-126.

34. Mendes, M.A.S.; Silva, V.L.; Dianese, J.C.; Ferreira, M.A.S.V.; Santos, C.E.N.; Neto, E.G.; Urben, A.F.; Castro, C. (1998). Fungos em plantas no Brasil. Embrapa - SPI, Brasília.

35. Mohan Babu, R.; Sajeena, A.; Vidhyasekaran, P.; Seetharaman, K.; Reddy, M. S. (2003). Characterization of a phytotoxic glycoprotein produced by Phoma eupyrena - A pathogen on water lettuce. Phytoparasitica 31, 265-274.

36. Muhammad, H.; Khan, A.S.; Khan, A.L.; Rehman, G.; Sohn, E.-Y.; Shah, A.A.; Kim, S.-K.; Joo, G.-J.; Lee, I.-J. (2009). Phoma herbarum as a New Gibberellin-Producing and Plant Growth-Promoting Fungus. $J$. Microbiol. Biotechnol. 19, 560-565.

37. Okane, I.; Nakagiri, A.; Ito, T. (1997). Preliminary study of endophytic fungi in evergreen plants from Ishigaki and Iriomote Islands. IFO Res. Commun. 18, 45-51.

38. Okane. I.; Nakagiri, A.; Ito, T. (2001). Assemblages of endophytic fungi on Bruguiera gymnorrhiza in the Shiira River Basin, Iriomote Is. IFO Res. Commun. 20, 41-49.

39. Pélaez, P.; Collado, J.; Arenal, P.; Basilio, A.; Cabello, A.; Matas, M.T.D.; Garcia, J.B.; Del Val, A.G.; Gonzáles, V.; Gorrochategui, J.; Hernández, P.; Martín, I.; Platas, G.; Vicente, P. (1998). Endophytic fungi from plants living on gypsum soils as a source of secondary metabolites with antimicrobial activity. Mycol. Res. 102, 755-761.

40. Pendle, S.; Weeks, K.; Priest, M.; Gill, A.; Hudson, B.; Kotsiou, G.; Pritchard, R. (2004). Phaeohyphomycotic Soft Tissue Infections Caused by the Coelomycetous Fungus Microsphaeropsis arundinis. J. Clin. Microbiol. 42, 5315-5319

41. Pereira, J.O.; Azevedo, J.L.; Petrini, O. (1993). Endophytic fungi of Stylosanthes: A first report. Mycologia 85, 362-364.

42. Petrini, O.; Dreyfuss, M. (1981). Endophytische Pilze in Epiphytischen Araceae, Bromeliaceae und Orchidaceae. Sydowia 34, 135-148.

43. Photita, W.; Lumyong, S.; Lumyong, P.; Hyde, K.D. (2001). Endophytic fungi of wild banana (Musa acuminata) at Doi Suthep Pui National Park, Thailand. Mycol. Res. 105, 1508-1513.

44. Ren, Y.; Strobel, G.A.; Graff, J.C.; Jutila, M.; Park, S.G.; Gosh, S.; Teplow, D.; Condron, M.; Pang, E.; Hess, W.M.; Moore, E. (2008). Colutellin A, an immunosuppressive peptide from Colletotrichum dematium. Microbiology 154, 1973-1979.

45. Rodrigues, K.F.; Samuels, G.J. (1990). Preliminary study of endophytic fungi in a tropical palm. Mycol. Res. 94, 827-830.

46. Rodrigues, K.F. (1991). Fungos endofíticos em Euterpe oleracea Mart., com ênfase em Xylariaceae. Bol. Museu Paraense Emilio Goeldi, Bot 7 , 429-439.

47. Rodrigues, K.F. (1994). The foliar fungal endophytes of the Amazonian palm Euterpe oleracea. Mycologia 86, 376-385.

48. Rodrigues, K.F.; Dias-Filho, M.B. (1996). Fungal endophytes in the tropical grasses Brachiara brizantha cv. Marandu and B. humidicola. 
Pesq. Agropec. Bras. 31: 905-909.

49. Rodrigues, K.F.; Samuels, G.J. (1999). Fungal endophytes of Spondias mombim leaves in Brazil. J. Basic Microbiol. 39,131-135.

50. Schulz, B.; Boyle, C. (2005). The endophytic continuum. Mycol. Res. 109, 661-686.

51. Silva, R.L.O.; Luz, J.S.; Silveira, E.B.; Cavalcante, U.M.T. (2006). Fungos endofíticos em Annona spp.: isolamento, caracterização enzimática e promoção do crescimento em mudas de pinha (Annona squamosa L.). Acta Bot. Bras. 20, 649-655.

52. Southcott, K.A.; Johnson, J.A. (1997). Isolation of endophytes from two species of palm from Bermudas. Can. J. Microbiol. 43, 789-792.

53. Souza, A.Q.L.; Souza A.D.L.; Astolfi Filho, S.; Pinheiro, M.L.B.; Sarquis, M.I.M.; Pereira, J.O. (2004). Atividade antimicrobiana de fungos endofíticos isolados de plantas tóxicas da Amazônia: Palicourea longiflora (Aubl.) Rich e Strychnos cogens Bentham. Acta Amazonica 34, 185-195.

54. Strobel, G.A.; Daisy, B. (2003). Bioprospecting for microbial endophytes and their natural products. Microbiol. Mol. Biol. Rev. 67, 491-502.

55. Suryanarayanan, T.S.; Kumaresan, V.; Johnson, J.A. (1998). Foliar fungal endophytes from two species of the mangrove Rhizophora. Can. J. Microbiol. 44, 1003-1006.

56. Suryanarayanan, T.S.; Kumaresan, V. (2000). Endophytic fungi of some halophytes from an estuarine mangrove forest. Mycol. Res. 104, 1465 1467.

57. Swizdor A.; Janeczko T.; Dmochowska-Gładysz J. (2010). Didymosphaeria igniaria: a new microorganism useful for the enantioselective reduction of aryl-aliphatic ketones. J. Ind. Microbiol. Biotechnol. PMID: 20544255.

58. Tomlinson, P.B. (1986). The Botany of Mangroves. Cambridge University Press, Cambridge.

59. Wang, B.; Priest, M.; Davidson, A.; Brubaker, C.L.; Woods, M.J.; Burdon, J.J. (2007). Fungal endophytes of native Gossypium species in Australia. Mycol. Res. 111, 347-354. 